\title{
Anti-inflammatory action of exendin-4 in human islets is enhanced by phosphodiesterase inhibitors: potential therapeutic benefits in diabetic patients
}

\author{
U. Pugazhenthi • K. Velmurugan - A. Tran • \\ G. Mahaffey $\cdot$ S. Pugazhenthi
}

Received: 29 March 2010 / Accepted: 14 June 2010 /Published online: 16 July 2010

(C) Springer-Verlag 2010

\begin{abstract}
Aims/hypothesis Exendin-4, a glucagon-like peptide-1 (GLP-1) analogue, is reported to have modest antiinflammatory effects in addition to that of improving beta cell survival. We therefore sought to determine whether exendin-4 decreases expression of the gene encoding chemokine (C-X-C motif) ligand (CXCL)10, which plays a role in initiating insulitis in type 1 diabetes.

Methods The expression of CXCL10 in human islets was determined at the mRNA level by real-time RT-PCR analysis and at the protein level by western blotting. The level of CXCL10 in culture medium was measured by ELISA. Pathway-specific gene expression profiling was carried out to determine the expression of a panel of genes encoding chemokines and cytokines in human islets exposed to cytokines.

Results IFN- $\gamma$ induced expression of CXCL10 through activation of signal transducer and activator of transcription1 (STAT-1). A combination of cytokines (IL- $1 \beta$, TNF- $\alpha$ and IFN- $\gamma$ ) showed strong synergy in the induction of numerous chemokines and cytokines through nuclear factor kappa B and STAT-1. Exendin-4 suppressed basal expression of several inflammatory mediators. In combination with phosphodiesterase inhibitors, exendin- 4 also decreased IFN- $\gamma$ -
\end{abstract}

Electronic supplementary material The online version of this article (doi:10.1007/s00125-010-1849-y) contains supplementary material, which is available to authorised users.

K. Velmurugan $\cdot$ A. Tran $\cdot$ G. Mahaffey $\cdot$ S. Pugazhenthi

Section of Endocrinology, Veterans Affairs Medical Center,

Denver, CO, USA

U. Pugazhenthi $\cdot$ K. Velmurugan $\cdot$ S. Pugazhenthi $(\varangle)$

Department of Medicine, University of Colorado Denver,

Mail Stop 8106, 12801 E 17th Ave,

Aurora, CO 80045, USA

e-mail: subbiah.pugazhenthi@ucdenver.edu induced $C X C L 10$ expression in human islets and in MIN6 cells (a mouse beta cell line), and its secretion into the culture medium. Exendin-4 action was mimicked by forskolin, an activator of adenylyl cyclase, and by dibutyryl cyclic AMP. Protein kinase A was not involved in mediating exendin-4 action on CXCL10. The mechanism of exendin-4's anti-inflammatory action involved decreases in STAT-1 levels.

Conclusions/interpretation These findings suggest that the GLP-1-cyclic AMP pathway decreases islet inflammation in addition to its known effects on beta cell survival.

Keywords Anti-inflammatory - cAMP. CXCL10 .

Cytokines $\cdot$ Diabetes $\cdot$ Exendin-4 $\cdot$ Interferon $-\gamma \cdot$ NF-kB .

STAT-1

$\begin{array}{ll}\text { Abbreviations } \\ \text { CREB } & \text { Cyclic AMP response element binding protein } \\ \text { CXCL } & \text { Chemokine (C-X-C motif) ligand } \\ \text { CXCR3 } & \text { Chemokine (C-X-C motif) receptor 3 } \\ \text { DBC } & \text { Dibutyryl cyclic AMP } \\ \text { GLP-1 } & \text { Glucagon-like peptide1 } \\ \text { JAK } & \text { Janus kinase } \\ \text { NF-kB } & \text { Nuclear factor kappa B } \\ \text { PKA } & \text { Protein kinase A } \\ \text { STAT-1 } & \text { Signal transducer and activator of transcription-1 }\end{array}$

\section{Introduction}

Glucagon-like peptide-1 (GLP-1), an incretin hormone secreted by enteroendocrine L cells of the gut, potentiates glucose-dependent insulin secretion in pancreatic beta cells. GLP-1 activates G-protein coupled receptors, leading to 
activation of adenylyl cyclase, which results in generation of cyclic AMP. This second messenger plays an important role in mediating the actions of GLP-1, although other signalling pathways are also involved [1]. Several studies have reported the anti-inflammatory action of cyclic AMP [2]. For example, the cytokine-activated janus kinase (JAK)-signal transducer and activator of transcription-1 (STAT-1) signalling pathway is inhibited by cyclic AMP in monocytes, in vascular endothelial cells and in hepatic stellate cells [3-5]. The effects of cyclic AMP are transient because it is degraded by phosphodiesterases. The isozymes of phosphodiesterase play important tissue-specific roles in the regulation of signalling pathways mediated by cyclic AMP. Anti-inflammatory actions of phosphodiesterase inhibitors in NOD mice and in BioBreeding rats have been reported $[6,7]$.

Chemokines are a family of $\sim 50$ proteins, consisting of 70-130 amino acids that play critical roles in recruitment of leucocytes at the site of inflammation [8]. There are two major families, termed $\mathrm{CC}$ and $\mathrm{CXC}$, depending on the arrangement of first two conserved cysteine residues near their $\mathrm{N}$ terminus. Chemokine (C-X-C motif) ligand (CXCL) 10 is secreted by various cell types, including keratinocytes, intestinal epithelial cells, endothelial cells, monocytes and neutrophils [9]. Diverse biological effects of this highly inducible chemokine have been reported [10]. CXCL10 stimulates $\mathrm{T}$ cell adhesion to endothelial cells, suppresses food intake and inhibits angiogenesis [11]. Chemokine (CX-C motif) receptor 3 (CXCR3), the receptor for CXCL10, is produced in several immune cell types including activated $\mathrm{T}$ cells and natural killer cells [10]. CXCL10 plays an important role in trafficking effector $\mathrm{T}$ cells to islets during insulitis in type 1 diabetes [12]. In NOD mice, CXCL10 production in islets is increased prior to initiation of insulitis [13]. CXCL10 neutralisation has been shown to suppress the incidence of diabetes in NOD mice [14]. Levels of CXCL10 are elevated in type 1 diabetic patients especially during early and subclinical stages [15]. Islets isolated from type 2 diabetic patients produce high levels of this chemokine [16]. A recent study with pancreatic tissues from four type 1 diabetic patients reported the presence of CXCL10 and infiltration of lymphocytes expressing the corresponding chemokine receptor CXCR3 in islets, regardless of enterovirus infection [17]. These studies suggest that suppression of CXCL10 production in islets could be an important therapeutic approach to reducing insulitis in type 1 diabetes. Recently, in human islets exposed to a combination of proinflammatory cytokines IL- $1 \beta$, TNF- $\alpha$ and IFN- $\gamma$, we observed induction of several chemokines, including CXCL10 [18]. The objective of this study was to determine whether exendin-4-mediated generation of cyclic AMP in human islets leads to suppression of cytokineinduced $C X C L 10$ expression.

\section{Methods}

Cell culture Human islets isolated from cadaveric donors were provided by Islet Cell Resource Center Human Islet Basic Science Distribution Program (City of Hope, Duarte, CA, USA). This study was approved by Institutional Ethics Committee. None of the donors had a previous history of diabetes (Electronic supplementary material [ESM] Table 1). Islets with purity of $80 \%$ to $95 \%$ and viability of $75 \%$ to 99\% were precultured for $24 \mathrm{~h}$ in Miami medium (CMRL 1066 medium [Mediatech, Hendon, VA, USA] supplemented with $0.5 \%$ [wt/vol.] human serum albumin and nicotinamide $[10 \mathrm{mmol} / 1])[18,19]$. Islets were exposed to IL-1 $\beta$ (50 U/ng), IFN- $\gamma(20 \mathrm{U} / \mathrm{ng})$ and TNF- $\alpha(100 \mathrm{U} / \mathrm{ng})$ (Roche Applied Science, Indianapolis, IN, USA), and rolipram and cilostamide (Enzo Life Sciences, Plymouth Meeting, PA, USA) or exendin-4 (Sigma Chemical, St Louis, MO, USA). MIN6 cells, a mouse pancreatic beta cell line [20] obtained from J. Miyazaki (First Department of Surgery, Kyoto University, Japan), were cultured in DMEM containing $5.6 \mathrm{mmol} / \mathrm{l}$ glucose, $10 \%$ (vol./vol.) FBS, $100 \mu \mathrm{g} / \mathrm{ml}$ streptomycin, $100 \mathrm{U} / \mathrm{ml}$ penicillin and $50 \mu \mathrm{mol} / 1 \beta$-mercaptoethanol at $37^{\circ} \mathrm{C}$ in a humidified atmosphere with $5 \% \mathrm{CO}_{2}$.

RNA isolation and RT-PCR analysis Total RNA was isolated from treated human islets using an isolation kit (Versagene RNA; Fisher Scientific, Pittsburgh, PA, USA). The mRNA levels of CXCL9, CXCL10 and CXCL11 were measured by real-time quantitative RT-PCR using Taqman probes. The primers and probes (ESM Table 2) were designed by Primer Express (PE ABI, Foster City, CA, USA). Amplicons corresponding to the amplification sequence were synthesised and used as standards in the RT-PCR analysis. mRNA levels of chemokines were expressed in ag/pg of GAPDH.

Western blot analysis Following treatment, human islets and MIN6 cells were washed with ice-cold PBS and cell lysates were prepared. Western blot analysis was performed by a procedure described previously [18] using CXCL10 (1:2000; R\&D Systems, Minneapolis, MN, USA), phospho STAT-1, STAT-1, phospho cyclic AMP response element binding protein (CREB) or CREB antibodies (1:1000; Cell Signaling, Danvers, MA, USA). After incubation with secondary antibodies conjugated to alkaline phosphatase, signals were developed with CDP-Star reagent (New England Biolabs, Beverly, MA, USA). The membranes were then stripped for $45 \mathrm{~min}$ at $55^{\circ} \mathrm{C}$ in buffer containing $62.5 \mathrm{mmol} / \mathrm{l}$ Tris-HCl, $\mathrm{pH} 6.7,2 \%$ (wt/vol.) SDS and $100 \mathrm{mmol} / \mathrm{l} \beta$-mercaptoethanol, and reprobed with $\beta$-actin antibody (Sigma). The intensity of bands was measured using Fluor-S MultiImager and Quantity One (Bio-Rad, Hercules, CA, USA) and corrected for the levels of $\beta$-actin. 
ELISA of CXCL10 CXCL10 released into the medium of cultured human islets and MIN6 cells was assayed using kits (DuoSet ELISA Development; R\&D Systems) for human or mouse CXCL10 respectively. A 96-well microplate was coated overnight with capture antibody for CXCL10 that was blocked for $1 \mathrm{~h}$ at room temperature with $1 \%$ (wt/vol.) BSA in PBS. The coated plates were incubated for $2 \mathrm{~h}$ at room temperature with samples of medium or CXCL10 standards. After washing, the plates were incubated with biotinylated detection antibody for another $2 \mathrm{~h}$ at room temperature. This was followed by incubation with streptavidin conjugated to horseradish peroxidase and colour development with $\mathrm{H}_{2} \mathrm{O}_{2}$ and tetramethylbenzidine. The plates were read at $450 \mathrm{~nm}$ with wavelength correction at $570 \mathrm{~nm}$. The concentration of CXCL10 was expressed as $\mathrm{pg} / \mathrm{ml}$ of medium.

Human inflammatory cytokines and receptors PCR array $\mathrm{A}$ PCR-based gene expression profiling specific to inflammatory pathway genes (PAHS-011A; SA Biosciences, Frederick, MD, USA) was carried out with total RNA isolated from treated human islets. RNA samples following DNase treatment were converted to cDNA [21]. Real-time PCR was performed with a sequence detector (ABI Prism 7700; Applied Biosystems, Foster City, CA, USA). The experimental cocktail was prepared by adding 1,278 $\mu$ l of the $\mathrm{RT}^{2}$ qPCR SYBR Green master mix (SA Biosciences) and $1,173 \mu \mathrm{H}_{2} \mathrm{O}$ to $102 \mu \mathrm{l}$ of the diluted cDNA; $25 \mu \mathrm{l}$ of this cocktail was added to each well of the 96-well PCR array plate containing primers for the 84 inflammatory pathway genes (Table 1), five housekeeping control genes, and three RNA and PCR quality controls. The thermal cycling conditions were: 1 cycle of $10 \mathrm{~min}$ at $95^{\circ} \mathrm{C}$, followed by 40 cycles of $15 \mathrm{~s}$ at $95^{\circ} \mathrm{C}$ and of $1 \mathrm{~min}$ at $60^{\circ} \mathrm{C}$. After amplification, real-time data acquisition and analysis were performed through the Data Analysis Web Portal (SA Biosciences). Data analysis was based on the $\Delta \Delta \mathrm{C}_{\mathrm{t}}$ method with normalisation of the raw data to $G A P D H$ as described in the manufacturer's manual.

ELISA of cyclic AMP The cyclic AMP levels were determined using a cyclic AMP assay kit (Parameter; R\&D
Biosystems). In this assay based on competitive binding, cell lysates and cyclic AMP standards are added to a microplate coated with antibody to cyclic AMP. A horseradish peroxidase-labelled cyclic AMP conjugate is also added. Cyclic AMP present in the samples competes with the fixed amount of horseradish peroxidase-labelled cyclic AMP conjugate for sites on the monoclonal antibody. After $2 \mathrm{~h}$ incubation, unbound sample and excess conjugate are removed by a wash. A substrate solution is added to the wells to determine bound enzymatic activity. Addition of stop solution halts colour development and absorbance is then measured at $450 \mathrm{~nm}$ with correction at $540 \mathrm{~nm}$.

Statistical analysis This was performed by one-way ANOVA with Dunnett's multiple comparison test.

\section{Results}

Suppression of IFN- $\gamma$-induced CXCR3-binding chemokines by exendin-4 and cyclic AMP in human islets CXCL9, CXCL10 and CXCL11 are ligands for immune cells expressing CXCR3 and play critical roles in the initiation of insulitis in type 1 diabetes. The mRNA levels of these chemokines, as measured by real-time RT-PCR analysis using Taqman probes, increased by 230 - to 265 -fold in islets following treatment with IFN- $\gamma$ when compared with untreated control. These induced levels were subsequently taken as $100 \%$ to determine the anti-inflammatory action of the GLP-1-cyclic AMP pathway. Exendin-4 in the presence of rolipram, an inhibitor of phosphodiesterase 4, which degrades cyclic AMP, suppressed IFN- $\gamma$-mediated induction of CXCL9 (24\%), CXCL10 (30\%) and CXCL11 (22\%; Fig. 1). Exendin-4 decreased CXCL10 modestly $(p<0.05)$ in the absence of rolipram. In subsequent experiments, exendin-4 was used along with a phosphodiesterase inhibitor to increase the levels of cyclic AMP generated. Forskolin, which generates cyclic AMP, and dibutyryl cyclic AMP (DBC), decreased IFN- $\gamma$-stimulated mRNA levels of the three chemokines more effectively ( $p<0.001$; Fig. 1 ), namely by $45 \%$ to $70 \%$ and $33 \%$ to $60 \%$, respectively.

Table 1 Functional gene grouping of inflammatory cytokines and receptors array

\begin{tabular}{|c|c|}
\hline Gene grouping & Genes \\
\hline Chemokines & C5, CCL1-5, CCL7, CCL8, CCL11, CCL13, CCL15-21, CCL23-26, CXCL1-6, CXCL9-14, IL8, IL13 \\
\hline Chemokine receptors & CCR1-9, CX3CR1, IL8RA, XCR1 \\
\hline Cytokines & CD40LG, IFNA2, IL1, IL5,IL8-10,IL13,IL22,IL1A,IL17C,IL1F5-10, LTA, LTB, MIF, SCYE1, SPP1, TNF \\
\hline Cytokine receptors & IFNA2, IL5RA, IL10RA, IL13RA, IL10RB, IL9, IL13, IL9R \\
\hline Others $^{\mathrm{a}}$ & $A B C F 1, B C L 6, C 3, C 4 A, C E B P B, C R P, I C E B E R G$ (also known as CARD18), IL1R1, IL1RN, IL8RB, LTB4R, TOLLIP \\
\hline
\end{tabular}

${ }^{\mathrm{a}}$ Involved in inflammatory response 
a

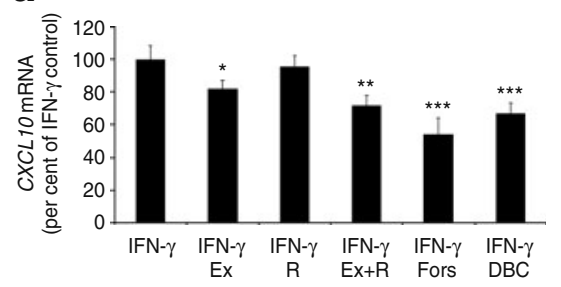

b

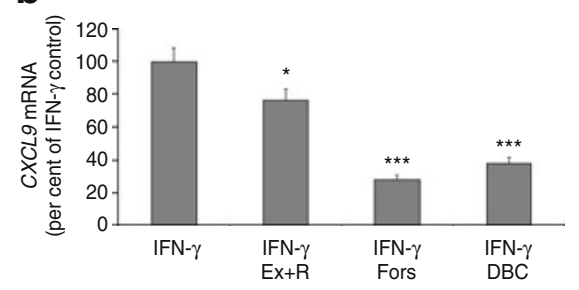

C

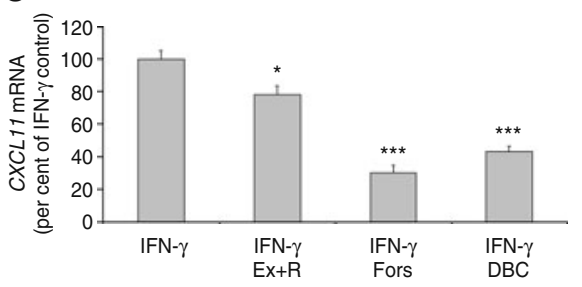

Fig. 1 Suppression of IFN- $\gamma$-induced expression of CXCR3-binding chemokines by exendin- 4 , rolipram, forskolin and DBC. Human islets (2,000 islet equivalents) were pre-incubated with $100 \mathrm{nmol} / 1$ exendin-4 (Ex), $15 \mu \mathrm{mol} / 1$ rolipram (R), $20 \mu \mathrm{mol} / 1$ forskolin (Fors) or $1 \mathrm{mmol} / 1 \mathrm{DBC}$ for $30 \mathrm{~min}$, followed by exposure to $2 \mathrm{ng} / \mathrm{ml} \mathrm{IFN}-\gamma$ for $6 \mathrm{~h}$. Total RNA was isolated from islets for real-time quantitative RT-PCR analysis of CXCL10 (a), CXCL9 (b) and CXCL11 (c), and expressed in ag/pg of $G A P D H$. Results are mean \pm SE from six independent batches of human islets. IFN- $\gamma$-induced chemokine levels were taken as $100 \%{ }^{*} p<0.05$; $* * p<0.01$ and $* * * p<0.001$ compared with IFN- $\gamma$ control
Decrease of IFN- $\gamma$-stimulated production of CXCL10 protein by exendin-4 and cyclic AMP in human islets Among the CXCR3 ligands, CXCL10 is considered to play a more significant role in initiation of insulitis in autoimmune diabetes. Therefore we examined the regulation of this chemokine in more detail. Exendin-4 with rolipram decreased CXCL10 protein levels by $38 \% \quad(p<0.01$; Fig. 2a), this decrease being reversed by SQ22536, an inhibitor of adenylyl cyclase, suggesting that cyclic AMP plays a role. Exendin-4 action was strongly $(p<0.001)$ mimicked by forskolin and $\mathrm{DBC}$, which decreased CXCL10 protein by $40-45 \%$ (Fig. 2b). Secretion of CXCL10 into the medium of cultured islets in the presence of IFN- $\gamma$ was also decreased by pre-incubation with exendin-4 (27\%), forskolin (70\%) and DBC (55\%; Fig. 2c).
Decreased production of STAT-1 by cyclic AMP generation in human islets Induction of CXCL10 by IFN- $\gamma$ has been shown to proceed through activation of the transcription factors STAT-1 and nuclear factor kappa B (NF-kB) [22]. We used: (1) a pan JAK inhibitor that blocks activation of STAT-1 by phosphorylation; and (2) Bay 11-7085, which decreases IkB phosphorylation and nuclear localisation of NF-kB. Increases in levels of CXCL10 protein stimulated by IFN- $\gamma$ were blocked by JAK inhibitor, but not by Bay 11-7085 as shown by ELISA of CXCL10 in culture medium (Fig. 3a) and by western blot analysis of islet lysates (Fig. 3b). This suggests that IFN- $\gamma$ action in human islets is primarily through STAT-1. Exendin-4, forskolin and DBC decreased the levels of STAT- 1 protein by $37 \%$ to $47 \%$ ( $p<0.01$; Fig. 3 c, d). a
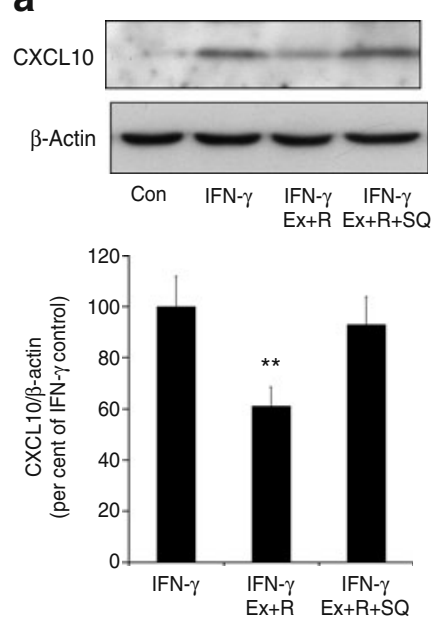

\section{b}


C

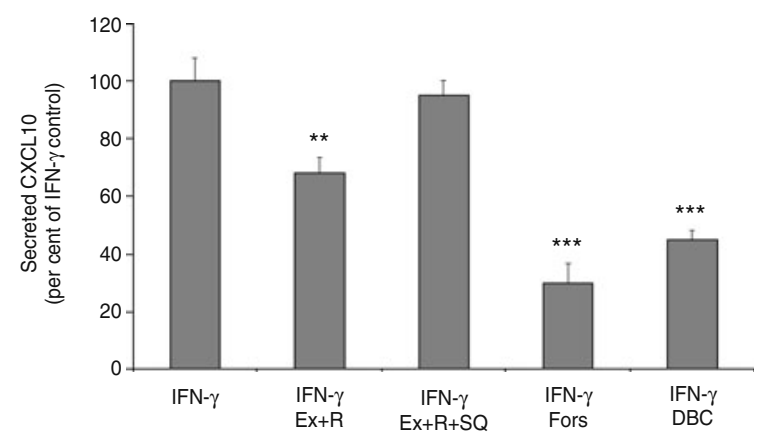

Fig. 2 Decrease of IFN- $\gamma$-stimulated production of CXCL10 protein by exendin-4, rolipram, forskolin and DBC. Human islets (2,000 islet equivalents) were pre-incubated with $100 \mathrm{nmol} / 1$ exendin-4 (Ex), $15 \mu \mathrm{mol} / 1$ rolipram (R), $100 \mu \mathrm{mol} / 1 \mathrm{SQ} 22536$ (SQ), $20 \mu \mathrm{mol} / 1$ forskolin (Fors) or $1 \mathrm{mmol} / \mathrm{l} \mathrm{DBC}$ for $30 \mathrm{~min}$, followed by exposure to $2 \mathrm{ng} / \mathrm{ml}$ of IFN- $\gamma$, for $6 \mathrm{~h}$, along with untreated control islets (Con). Treated islets were processed for western blot analysis of CXCL10 (a, b). The blots were reprobed for $\beta$-actin and band intensities determined by scanning. Band intensity is presented as ratio of CXCL10/ $\beta$-actin. c Levels of secreted CXCL10 in the medium were determined by ELISA. The results are mean $\pm \mathrm{SE}$ from five independent batches of human islets. IFN- $\gamma$-induced CXCL10 levels were taken as $100 \%$. ${ }^{* *} p<$ 0.01 and $* * * p<0.001$ compared with IFN- $\gamma$ control 
a

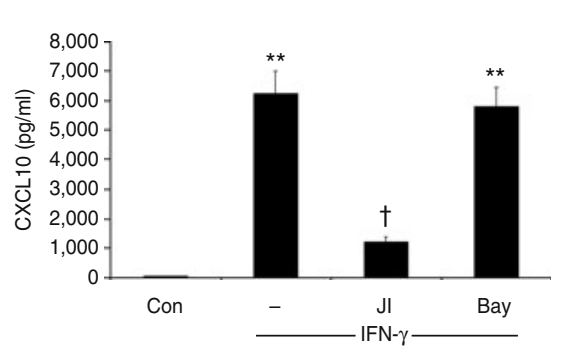

b

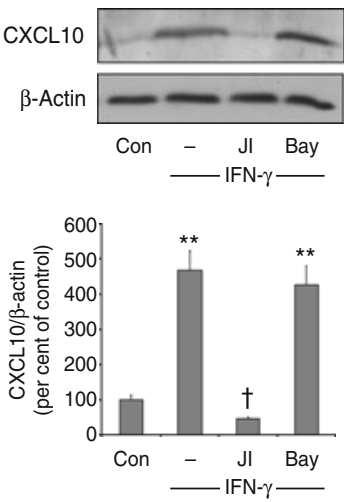

C
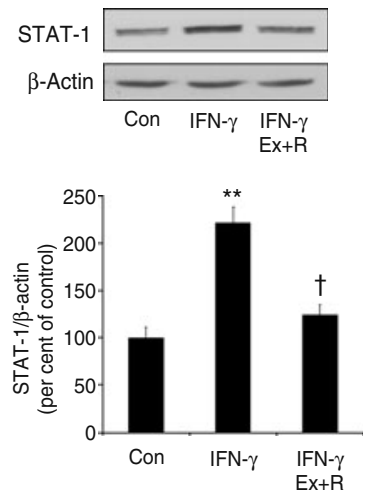

d
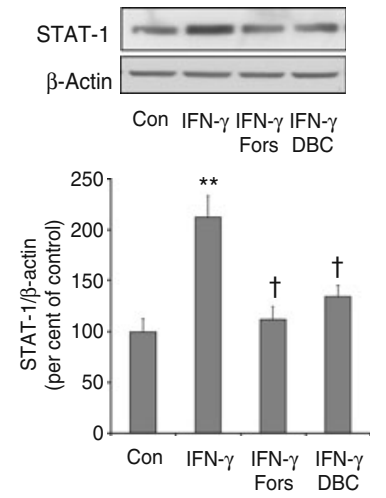

Fig. 3 Decrease of IFN- $\gamma$-stimulated production of STAT-1 by the GLP-1-cyclic AMP pathway. a, b Human islets $(2,000$ islet equivalents [IEQ]) were pre-incubated for $30 \mathrm{~min}$ in the presence of $1 \mu \mathrm{mol} / 1$ pan JAK inhibitor (JI) or $15 \mu \mathrm{mol} / 1$ Bay 11-7085 (Bay), an inhibitor of NF-kB, followed by exposure to $2 \mathrm{ng} / \mathrm{ml}$ of IFN- $\gamma$ for $6 \mathrm{~h}$, along with untreated control islets (Con). Medium was collected to determine levels of CXCL10 by ELISA (a). Islets were processed for western blot analysis and quantification of CXCL10 and $\beta$-actin (b). c, d Human islets (2,000 IEQ) were pre-incubated for $30 \mathrm{~min}$ with $100 \mathrm{nmol} / \mathrm{l}$ exendin-4 (Ex) and $15 \mu \mathrm{mol} / 1$ rolipram (R), and $20 \mu \mathrm{mol} / \mathrm{l}$ forskolin (Fors) or $1 \mathrm{mmol} / \mathrm{l} \mathrm{DBC}$, followed by exposure


blot analysis and quantification of STAT-1. The blots were reprobed for $\beta$-actin and band intensities determined by scanning. Results are mean \pm $\mathrm{SE}$ from five independent batches of human islets. ${ }^{* *} p<0.01$ vs untreated control; ${ }^{\dagger} p<0.01$ compared with IFN- $\gamma$ control
Synergistic induction of CXCL10 by cytokines in human islets Experiments described thus far examined the antiinflammatory action of the GLP-1-cyclic AMP pathway in human islets exposed to IFN- $\gamma$. Following infiltration of islets with immune cells, insulitis is sustained through induction of $C X C L 10$ by proinflammatory cytokines IL-1 $\beta$, TNF- $\alpha$ and IFN- $\gamma$ released by immune cells. Therefore human islets were exposed to these cytokines, alone or in combination. IL-1 $\beta$ and TNF- $\alpha$ did not induce CXCL10 expression even at a concentration of $5 \mathrm{ng} / \mathrm{ml}$, whereas IFN- $\gamma$ increased $C X C L 10$ mRNA by 200 - to 500 -fold at 2 to $5 \mathrm{ng} / \mathrm{ml}$ (Fig. 4a). When a combination of all three cytokines was used, synergistic induction was observed as shown by the 700- to 1,000-fold increase in CXCL10 mRNA levels. Western blot analysis revealed similar synergy between cytokines in CXCL10 protein production in islets (Fig. 4b). The secretion of CXCL10 into the medium was measured by ELISA and the findings were consistent with the western blot analysis results (Fig. 4c).

Suppression of cytokine-induced CXCL10 expression by cyclic AMP generation in human islets Although inhibition of NF-kB did not decrease IFN- $\gamma$-induced CXCL10 production (Fig. 3a, b), CXCL10 induction by a combination of cytokines was decreased by Bay 11-7085 alone and more effectively when Bay 11-7085 was used in combination with JAK inhibitor (Fig. 5a). Because CXCL10 induction was significantly greater in the presence of a combination of cytokines, we used rolipram and cilostamide, inhibitors of phosphodiesterase 4 and 3 respectively, a

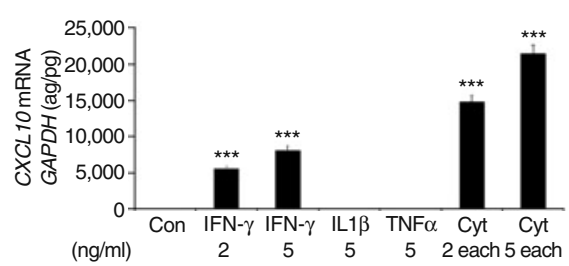

b

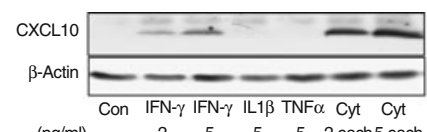

$(\mathrm{ng} / \mathrm{ml}) \quad \begin{array}{ccccc} & 5 & 5 & 5 & 2 \text { each } 5 \text { each }\end{array}$



C

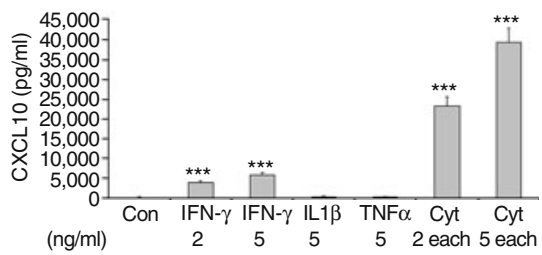

Fig. 4 Synergistic induction of CXCL10 by IL- $1 \beta$, TNF- $\alpha$ and IFN- $\gamma$ in human islets. Human islets (2,000 islet equivalents) were exposed to indicated doses of IFN- $\gamma$, IL- $1 \beta$ and TNF- $\alpha$ alone or a combination of all three (Cyt) for $6 \mathrm{~h}$. a Total RNA was isolated from islets for RTPCR analysis of CXCL10. b Islets were processed for western blot analysis and quantification of CXCL10, and blots were reprobed for $\beta$-actin. A representative blot is shown. Band intensities of CXCL10 were determined by scanning and corrected for levels of $\beta$-actin. c Levels of secreted CXCL10 in the medium were determined by ELISA. The results are mean \pm SE from five independent batches of human islets. $* * * p<0.001$ compared with untreated control 
a

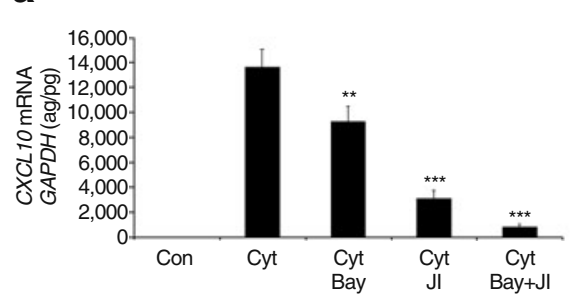

b

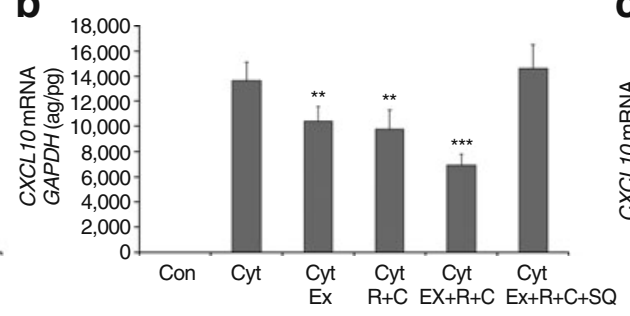

C

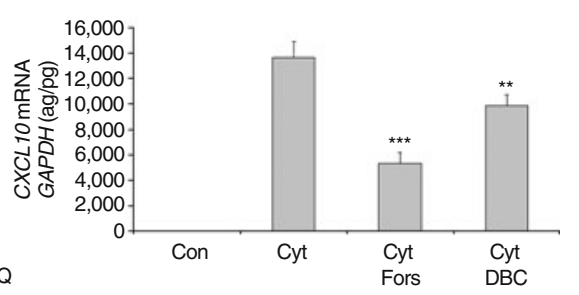

Fig. 5 Suppression of cytokine-induced expression of CXCL10 by cyclic AMP generation in human islets. Human islets $(2,000$ islet equivalents) were pre-incubated for $30 \mathrm{~min}$ with $15 \mu \mathrm{mol} / 1$ Bay 11-7085 (Bay) and $1 \mu \mathrm{mol} / \mathrm{l} \mathrm{JAK}$ inhibitor (JI) (a), with $100 \mathrm{nmol} / 1$ exendin4 (Ex), $15 \mu \mathrm{mol} / 1$ rolipram (R), $10 \mu \mathrm{mol} / 1$ cilostamide (C) and $100 \mu \mathrm{mol} / 1 \mathrm{SQ} 22536$ (SQ) (b), and with $20 \mu \mathrm{mol} / 1$ forskolin (Fors) or $1 \mathrm{mmol} / \mathrm{l} \mathrm{DBC}$ (c), followed by exposure to $2 \mathrm{ng} / \mathrm{ml}$ each of IL$1 \beta$, TNF- $\alpha$ and IFN- $\gamma(\mathrm{Cyt})(\mathbf{a}-\mathbf{c})$ as indicated for $6 \mathrm{~h}$. Total RNA was isolated from islets for the RT-PCR analysis of CXCL10 and corrected for levels of $G A P D H$. Results are mean \pm SE from five independent batches of human islets. ${ }^{* *} p<0.01$ and ${ }^{* * *} p<0.001$ compared with cytokine control to enhance the anti-inflammatory action of exendin-4. Pancreatic beta cells are known to contain these two phosphodiesterase isozymes. Exendin-4 and phosphodiesterase inhibitors inhibited $C X C L 10$ by $24 \%$ and $28 \%$ respectively; when used together, $50 \%$ inhibition was observed (Fig. 5b). Exendin-4-mediated suppression of CXCL10 was lost in the presence of an adenylyl cyclase inhibitor (SQ22536). Forskolin and DBC inhibited cytokine-induced CXCL10 expression by $61 \%$ and $28 \%$ respectively (Fig. 5c).

Suppression of cytokine-induced expression of genes encoding chemokines by inhibitors of NF- $k B$ and STAT-1 pathways, and by cyclic AMP generation in human islets To determine whether the anti-inflammatory action of exendin- 4 is seen with other inflammatory mediators, a pathway-specific gene expression profiling of 84 genes in the inflammatory pathway (Table 1) was carried out in islets under basal conditions and following stimulation with a combination of IL- $1 \beta$, TNF- $\alpha$ and IFN- $\gamma$. Exendin- 4 decreased the basal expression of several chemokines and cytokines in human islets by $20 \%$ to $45 \%$ even in the absence of phosphodiesterase inhibitors (Table 2). When islets were stimulated with a combination of cytokines, several chemokines in the CCL and CXCL family were induced (Table 3 ). In addition, the cytokines $I L 17 C, I L 1 A, I L 1 B, I L 8$ and TNF- $\alpha$ (also known as $T N F$ ) were also induced. A combination of inhibitors of the NF-kB and JAK-STAT-1 pathways suppressed (17-96\%) all the inflammatory mediators except $C C L 2, C C L 7$ and $I L 8$. Exendin- 4 in the presence of phosphodiesterase inhibitors reduced expression of $C C L 2, C C L 3, C C L 4, C C L 7, C C L 20$, CXCL6, CXCL9, CXCL10, CXCL11, IL1B and IL8 by $20 \%$ to $30 \%$.

Regulation of CXCL10 production by cytokines in MIN6 cells To determine the regulation of CXCL10 production by cytokines specifically in beta cells, we used MIN6 cells, a mouse beta cell line. Among the cytokines tested, both IFN- $\gamma$ and IL-1 $\beta$ were equally effective in increasing CXCL10 production (Fig. 6a, c), unlike in human islets (Fig. 4). A synergistic effect between the cytokines IL-1 $\beta$, TNF- $\alpha$ and IFN- $\gamma$ in the production of CXCL10 was observed, as in human islets. IFN- $\gamma$-mediated increase in CXCL10 protein was blocked by JAK inhibitor, which also decreased STAT-1 phosphorylation and STAT-1 production (Fig. 6b). These findings were further confirmed by ELISA

Table 2 Suppression of chemokines and cytokines by exendin- 4 in human islets

\begin{tabular}{llllll}
\hline CCL chemokines & Per cent of control & CXCL chemokines & Per cent of control & Cytokines & Per cent of control \\
\hline$C C L 2$ & $57.8^{* * *}$ & $C X C L 2$ & $67.4^{* *}$ & ILI7C & $67.4^{* *}$ \\
$C C L 3$ & $65.2^{* *}$ & $C X C L 5$ & $74.8^{* *}$ & ILIA & $61.1^{* * *}$ \\
$C C L 4$ & $61.3^{* * *}$ & $C X C L 6$ & $52.1^{* * *}$ & $I L 1 B$ & $68.3^{* *}$ \\
$C C L 5$ & $58.7^{* * *}$ & $C X C L 9$ & $79.2^{*}$ & $54.3^{* * *}$ \\
$C C L 7$ & $80.1^{* *}$ & $C X C L 10$ & $55.1^{* * *}$ & $T N F$ & $67.2^{* *}$ \\
$C C L 8$ & $54.7^{* * *}$ & $C X C L 11$ & $62.3^{* * *}$ & & \\
\hline
\end{tabular}

Results are an average of four independent experiments

Human islets were incubated in the absence and presence of $100 \mathrm{nmol} / 1$ exendin- 4 for $18 \mathrm{~h}$. Total RNA was isolated and PCR-based gene expression profiling of genes specific to the inflammatory pathway was carried out

${ }^{*} p<0.05,{ }^{* *} p<0.01$ and $* * * p<0.001$ compared with untreated islet controls 
Table 3 Suppression of cytokine-induced chemokines by cyclic AMP generation and by inhibitors of NF-kB and STAT-1 pathways

\begin{tabular}{|c|c|c|c|c|c|c|}
\hline \multirow[t]{2}{*}{ Chemokine and cytokine genes } & \multicolumn{6}{|c|}{ Fold induction over untreated control } \\
\hline & Cyt & $\mathrm{R}+\mathrm{C}+\mathrm{Ex} \mathrm{Cyt}$ & DBC Cyt & Bay Cyt & JI Cyt & Bay+JI Cyt \\
\hline CCL2 & 5.5 & $4.4^{*}$ & $2.475^{* * *}$ & 5.94 & 5.115 & 5.005 \\
\hline$C C L 3$ & 6.4 & $2.56^{* * *}$ & $2.112^{* * *}$ & $5.248^{*}$ & $4.864^{*}$ & $4.096^{* *}$ \\
\hline CCL4 & 2.2 & $1.738^{*}$ & $1.386^{* *}$ & 2.772 & $1.782^{*}$ & $1.826^{*}$ \\
\hline CCL5 & 15.7 & 18.055 & $8.792^{* * *}$ & 13.816 & $0^{* * *}$ & $3.768^{* * *}$ \\
\hline$C C L 7$ & 3.7 & $2.923^{*}$ & $2.923^{*}$ & 5.18 & 3.367 & 4.773 \\
\hline$C C L 8$ & 4.2 & 4.116 & 4.326 & 4.536 & $1.89^{* * *}$ & $2.016^{* * *}$ \\
\hline CCL11 & 2.4 & 3.144 & 3.48 & 2.112 & $1.848^{*}$ & $1.032^{* * *}$ \\
\hline CCL2O & 86.5 & $66.605^{*}$ & 80.445 & $71.795^{*}$ & 78.715 & $69.2^{*}$ \\
\hline$C X C L 1$ & 56.3 & 49.544 & 61.93 & 50.67 & 55.737 & $45.603^{*}$ \\
\hline CXCL2 & 32.3 & 35.207 & 44.574 & $26.486^{*}$ & 32.623 & $20.349^{* *}$ \\
\hline CXCL3 & 30.9 & 30.9 & $23.484^{*}$ & $25.647^{*}$ & $25.647^{*}$ & $17.613^{* *}$ \\
\hline CXCL5 & 36.1 & 34.295 & 65.702 & $25.992^{*}$ & 49.818 & $23.826^{* *}$ \\
\hline CXCL6 & 38.1 & $27.813^{*}$ & 34.671 & $32.004^{*}$ & 54.483 & $31.242^{*}$ \\
\hline CXCL9 & 415 & $319.55^{*}$ & $215.8^{* * * *}$ & 385.95 & $45.65^{* * *}$ & $16.6^{* * *}$ \\
\hline CXCL10 & 135 & $91.8^{* * *}$ & $74.25^{* * *}$ & 117.45 & $27^{* * *}$ & $9.45^{* * *}$ \\
\hline CXCL11 & 119 & $94.01^{*}$ & $79.73^{* *}$ & $92.82^{*}$ & $24.99^{* * *}$ & $10.71^{* * *}$ \\
\hline$I L 17 C$ & 9.3 & 11.625 & 12.741 & $5.301^{* * *}$ & $2.418^{* * * *}$ & 1.674 \\
\hline ILIA & 34.6 & 34.254 & 38.406 & $29.064^{*}$ & $28.718^{*}$ & $25.95^{*}$ \\
\hline$I L 1 B$ & 21.6 & $16.416^{*}$ & 19.44 & $17.928^{*}$ & $15.12^{*}$ & $11.664^{* *}$ \\
\hline IL8 & 35.2 & $26.752^{*}$ & $28.512^{*}$ & 30.976 & 37.312 & 45.056 \\
\hline$T N F$ & 2.54 & 2.3114 & 2.3368 & 3.2766 & $2.0066^{*}$ & $2.0066^{*}$ \\
\hline
\end{tabular}

Values represent mean fold induction over untreated islets from four independent experiments

Human islets (2,000 islet equivalents) were pre-incubated with $100 \mathrm{nmol} / 1$ of exendin-4 (Ex), $15 \mu \mathrm{mol} / 1$ rolipram (R), $10 \mu \mathrm{mol} / 1$ cilostamide (C), $1 \mathrm{mmol} / 1 \mathrm{DBC}, 15 \mu \mathrm{mol} / 1$ Bay 11-7085 (Bay) and $1 \mu \mathrm{mol} / 1 \mathrm{JAK}$ inhibitor (JI) as indicated for $30 \mathrm{~min}$, followed by exposure to a combination of $2 \mathrm{ng} / \mathrm{ml}$ each of IL-1 $\beta$, TNF- $\alpha$ and IFN- $\gamma$ (Cyt) for $6 \mathrm{~h}$. Total RNA was isolated and PCR-based expression profiling of genes specific to the inflammatory pathway was carried out

${ }^{*} p<0.05, * * p<0.01$ and $* * * p<0.001$

of secreted CXCL10 in the culture medium. Although Bay 11-7085 did not decrease CXCL10 release into culture medium, it did enhance the inhibitory effects of JAK inhibitor (Fig. 6c).

Suppression of IFN- $\gamma$-mediated CXCL10 production by cyclic AMP generation through decrease in the levels of STAT-1 in MIN6 cells To determine whether the antiinflammatory action of exendin-4 in human islets can be extended to beta cells, we examined the abundance of CXCL10 in MIN6 cells pre-incubated with exendin-4 and phosphodiesterase inhibitors. IFN- $\gamma$-mediated increase in CXCL10 protein level was significantly $(p<0.01)$ decreased by exendin-4 (21\%), rolipram (24\%) and cilostamide $(23 \%)$, whereas a combination of these three resulted in an additive decrease $(57 \% ; p<0.001)$ of CXCL10 protein (Fig. 7a). Inhibition of adenyl cyclase with SQ22536 partially reversed CXCL10 suppression by exendin- 4 and phosphodiesterase inhibitors (Fig. 7b). Exendin-4 action on chemokine levels was mimicked by forskolin and DBC (Fig.7c). IFN- $\gamma$-stimulated increase in the levels of STAT-1 was significantly $(45 \% ; p<0.01)$ inhibited by exendin- 4 and phosphodiesterase inhibitors (Fig. 7d).

Sustained release of cyclic AMP by exendin-4 in the presence of phosphodiesterase inhibitors in MIN6 cells Our results described thus far suggest increased production of cyclic AMP by exendin- 4 in the presence of phosphodiesterase inhibitors. Therefore we measured the levels of this second messenger in exendin-4-treated MIN6 cells. The levels of cyclic AMP in MIN6 cells increased by twofold in the presence of exendin- 4 and by 3.5 -fold in the presence of exendin-4 and phosphodiesterase inhibitors, compared with untreated cells (Fig. 8a). CREB, an anti-apoptotic transcription factor that mediates the effects of exendin-4, is phosphorylated by cyclic AMP-activated protein kinase A (PKA) [19]. Therefore we determined the levels of phosphorylated CREB as a measure of increase in cyclic 

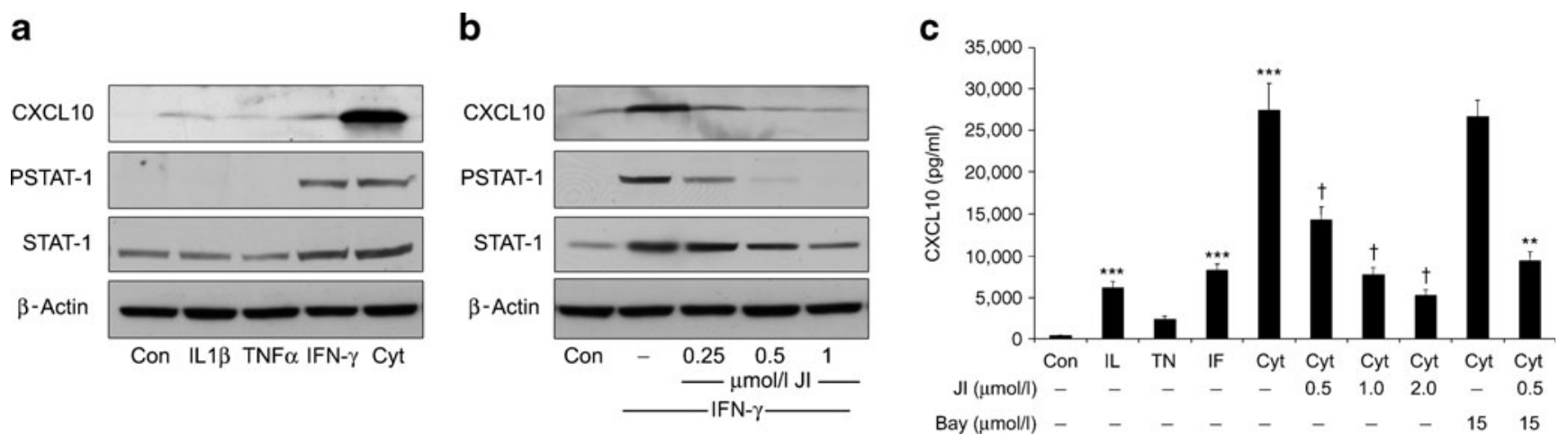

Fig. 6 Regulation of CXCL10 production by cytokines in MIN6 cells. MIN6 cells were exposed to $2 \mathrm{ng} / \mathrm{ml}$ of IL- $1 \beta$, TNF- $\alpha$ and IFN- $\gamma$ alone or in combination (Cyt) for $18 \mathrm{~h} \mathrm{(a)} \mathrm{or} \mathrm{pre-incubated} \mathrm{in} \mathrm{the}$ presence of indicated concentrations of JAK inhibitor (JI) followed by exposure to $2 \mathrm{ng} / \mathrm{ml}$ of IFN- $\gamma$ for $18 \mathrm{~h}$ (b). Treated MIN6 cells were processed for western blot analysis of CXCL10, phosphorylated and total forms of STAT-1 and $\beta$-actin. c MIN6 cells were incubated in the

AMP levels. Exendin-4-mediated CREB phosphorylation increased by twofold at $15 \mathrm{~min}$, but decreased gradually over the following 30 to $60 \mathrm{~min}$, probably due to phosphodiesterase-mediated degradation of cyclic AMP

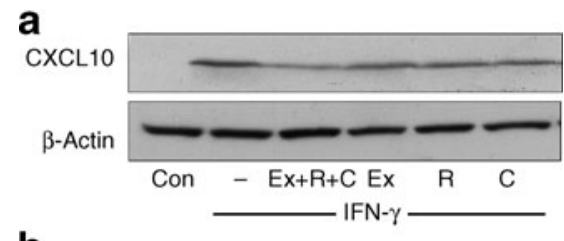

b



C

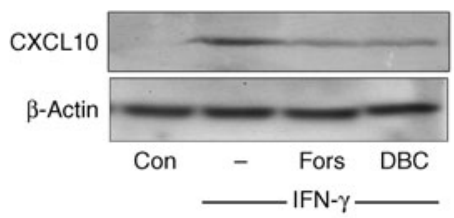

d



Fig. 7 Suppression of IFN- $\gamma$-induced CXCL10 production by GLP-1cyclic AMP pathway through decrease of STAT-1. MIN6 cells were exposed to IFN- $\gamma$-as indicated and to: (a) exendin-4 (Ex), rolipram (R) and cilostamide $(\mathrm{C})$, alone and together; $(\mathbf{b})$ to $\mathrm{Ex}+\mathrm{R}+\mathrm{C}$ and adenylyl cyclase inhibitor SQ22536 (SQ) as indicated; (c) to forskolin (Fors) and $\mathrm{DBC}$; and (d) to $\mathrm{Ex}, \mathrm{R}+\mathrm{C}$ and $\mathrm{Ex}+\mathrm{R}+\mathrm{C}$. Concentrations were as indicated in Fig. 4, exposure was for $18 \mathrm{~h}$. Treated cells were processed for western blot analysis of CXCL10, STAT-1 or $\beta$-actin presence of cytokines and inhibitors as indicated for $18 \mathrm{~h}$ and levels of CXCL10 secreted into the culture medium were determined by ELISA. The results are mean $\pm \mathrm{SE}$ from four independent experiments. ${ }^{*} p<0.01$ compared with MIN6 cells incubated in the presence of cytokines and $0.5 \mu \mathrm{mol} / 1$ of JAK inhibitor; $* * * p<0.001$ compared with untreated control; ${ }^{\dagger} p<0.001$ vs a combination of cytokines

(Fig. 8b). In the presence of rolipram and cilostamide, exendin-4-mediated CREB phosphorylation increased by 3.8 -fold and was sustained over a 15 to 60 min period. Phosphodiesterase inhibitors also increased the level of phosphorylated CREB by 2.3 -fold in the absence of exendin-4, suggesting that phosphodiesterase plays a role in degradation of cyclic AMP under basal conditions.

Protein kinase $A$ is not involved in cyclic AMP-mediated suppression of CXCL10 levels in MIN6 cells To delineate the role of PKA-dependent and -independent pathways of cyclic AMP action, we used the PKA inhibitor, H89. Inhibition of PKA decreased cyclic AMP-mediated CREB phosphorylation, as expected (Fig. 8c). However, suppression of IFN- $\gamma$-stimulated CXCL10 production by exendin- 4 and phosphodiesterase inhibitors was not reversed by H89 (Fig. 8d). This observation suggests that the cyclic AMPmediated decrease of CXCL10 is unlikely to proceed through PKA. Surprisingly, in human islets, CXCL10 suppression by cyclic AMP was further enhanced by H89 (results not shown), probably via inhibition of a feedback regulation by PKA.

\section{Discussion}

Chemokines play an important role in the initiation of insulitis in type 1 diabetes and in islet graft rejection [12, $13,23,24]$. In this study, we demonstrate that exendin-4mediated suppression of CXCL10 expression is enhanced by phosphodiesterase inhibitors in human islets and in a mouse beta cell line. Similar and stronger suppression of CXCL10 was observed in islets treated with: (1) forskolin, which generates cyclic AMP by activation of adenylyl cyclase; and (2) DBC, a non-degradable cyclic AMP 
a

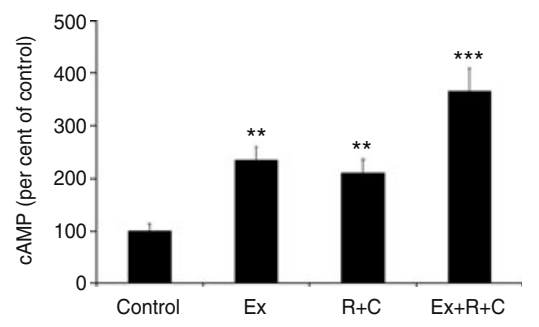

b
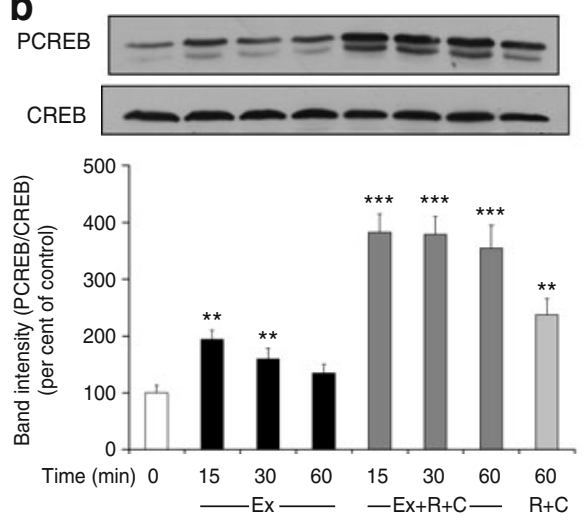

C

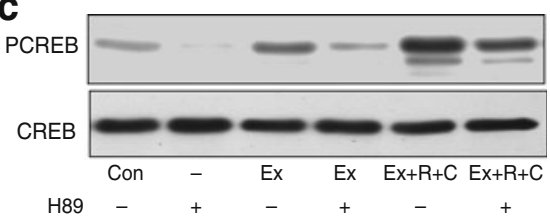

d



Fig. 8 Sustained release of cyclic AMP (cAMP) by exendin- 4 in the presence of phosphodiesterase inhibitors. MIN6 cells were preincubated in the presence of $10 \mu \mathrm{mol} / 1$ each of rolipram (R) and cilostamide $(\mathrm{C})$, followed by incubation in the absence and presence of $100 \mathrm{nmol} / 1$ exendin-4 (Ex). Incubation was for $1 \mathrm{~h} \mathrm{(a)} \mathrm{or} \mathrm{for} \mathrm{the}$ indicated times (b). c, d MIN6 cells were also pre-incubated in the

analogue. These agents also decreased levels of STAT-1, a transcription factor through which IFN- $\gamma$ induces CXCL10. PKA does not appear to play a role in mediating the action of cyclic AMP on CXCL10. The anti-inflammatory action of the GLP-1-cyclic AMP pathway was also seen with several other inflammatory mediators generated by human islets. These findings have potential implications for the treatment of diabetes and improvement of islet transplantation outcomes.

IFN- $\gamma$ was found to be a strong inducer of CXCL10, whereas IL- $1 \beta$ and TNF- $\alpha$ did not increase expression of CXCL10 in human islets (Fig. 4). It is surprising that IL-1 $\beta$ and TNF- $\alpha$, which are known to induce CXCL10 in other cell types [25], did not have a significant effect on this chemokine in human islets. However, there was a strong synergy when a combination of these three cytokines was used [18]. The synergy between cytokines could be due to the involvement of multiple transcription factors in the induction of CXCL10. Majumder et al. (1998) have demonstrated the role of STAT-1 and NF-kB in the induction of CXCL10 by IFN- $\gamma$ and TNF- $\alpha$ [22]. A pathway-specific gene expression profiling analysis revealed induction of a panel of chemokines (CCL2, CCL3, CCL4, CCL5, CCL7, CCL8, CCL11, CCL20, CXCL1, CXCL2, CXCL3, CXCL5, CXCL6, CXCL9, CXCL10, CXCL11) and cytokines (IL17C, IL1A, IL1B, $I L 8$ and $T N F-\alpha)$ in human islets following exposure to IL$1 \beta$, TNF- $\alpha$ and IFN- $\gamma$. The transcription factors NF-kB and STAT-1 seem to be involved in the induction of all these inflammatory mediators except CCL2, CCL7 and IL8. The anti-inflammatory action of exendin- 4 and phosphodiesterase inhibitors was seen with CCL2, CCL3, CCL4, CCL7, CCL20, CXCL6, CXCL9, CXCL10, CXCL11, IL1B and IL8. Islet-generated chemokines could play a role in beta presence of $10 \mu \mathrm{mol} / 1 \mathrm{H} 89$, an inhibitor of protein kinase A, followed by exposure to exendin- 4 and phosphodiesterase inhibitors as indicated. The cell lysates were processed for determination of cyclic AMP levels by ELISA (a) or for western blot analysis of PCREB and CREB (b, c) or CXCL10 (d). ${ }^{* *} p<0.01$ and $* * * p<0.001$ with respect to untreated control

cell death in addition to causing insulitis. Impairment of beta cell function in human islets exposed to CXCL10 has been reported [16].

GLP-1 is known to increase proliferation and neogenesis of beta cells, and to prevent their death by apoptosis [1]. Inhibitors of dipeptidyl peptidase-IV, which is known to increase circulating levels of GLP-1, and degradationresistant GLP-1 analogues are being used in the treatment of type 2 diabetes to preserve beta cell mass [26]. Antiinflammatory action of GLP-1 has been suggested by Iwai et al. (2006), who reported the inhibition of lipopolysaccharideinduced IL-1 $\beta$ production in cultured rat astrocytes by GLP1 through generation of cyclic AMP [27]. Exendin-4 has also been reported to decrease microglia-derived TNF- $\alpha$ and IL$1 \beta$ in mouse brain [28]. Several in vivo studies have reported the beneficial effects of exendin-4 in NOD mice. For example, chronic administration of exendin-4 to NOD mice leads to modest and significant decrease in insulitis [29]. Continuous infusion of GLP-1 also delayed the onset of diabetes in NOD mice [30]. Other studies have used exendin-4 in combination with anti-inflammatory agents to demonstrate a more significant blocking of insulitis and diabetes onset in NOD mice [31-33]. Furthermore, a recent study has reported that increasing the levels of circulating GLP-1 by inhibiting dipeptidyl peptidase-IV results in prolonged islet graft survival and decreased insulitis in diabetic NOD mice [34]. The mechanism of antiinflammatory action of exendin-4 could involve downregulation of STAT-1. STAT1 is an autoregulated gene induced by IFN- $\gamma$ (Fig. 6). Exendin-4 is reported to decrease basal mRNA levels of JAK1 and STAT1 in human islets and in INS-1 cells, a rat insulinoma cell line [35]. We observed here a decrease in IFN- $\gamma$-stimulated 
STAT-1 protein levels pre-incubated with exendin-4 and phosphodiesterase inhibitors (Figs 3c, 7d).

Induction, triggered by viral infection, of CXCL10 expression in islets has been suggested to play a role in initiating insulitis in type 1 diabetes [12]. In a lymphocytic choriomeningitis virus-induced mouse model of autoimmune diabetes, increased expression of CXCR3-binding chemokines was reported as an important early event initiating islet infiltration with immune cells [36]. Cultured human islets have been shown to secrete CXCL10 following enterovirus infection [37]. In a recent report, Tanaka et al. examined sections of pancreas from autopsy material derived from a deceased patient with fulminant type 1 diabetes, an acute subtype of type 1 diabetes identified in the Japanese population, and detected enterovirus capsid protein infiltration of CXCR3-bearing $\mathrm{T}$ cells and macrophages [38]. They also observed IFN- $\gamma$ and CXCL10 in all subtypes of islets. Another recent study has observed the presence of CXCL10 and infiltration of lymphocytes expressing the corresponding chemokine receptor $C X C R 3$ in islets from pancreatic tissues of deceased recent-onset type 1 diabetic patients, regardless of enterovirus infection; this suggests a significant role for this chemokine in inducing insulitis [17]. Viral infection can also cause direct injury to beta cells [39]. Coxsackievirus-induced beta cell death in cultured human islets has been reported [40]. Double-stranded RNA, generated in virus-infected cells, induces the pro-apoptotic gene $F A S$ and synergises with cytokines in inducing apoptosis in rodent beta cells [41].

The role of inflammatory mediators in type 2 diabetes is also being recognised $[42,43]$. The presence of immune cells in islets from human type 2 diabetic patients and from animal models of type 2 diabetes has been reported [44]. Chronic infiltration of diabetic islets with immune cells could play a significant role in beta cell death in type 2 diabetes through release of cytokines and chemokines. Thus our findings of an anti-inflammatory action of exendin- 4 have implications for the treatment of both types of diabetes.

Targeting beta cell/islet-generated chemokines could be a potential therapeutic approach along with conventional anti-inflammatory therapy directed against immune cells. Infiltration of islets in type 1 diabetes is preceded by changes in islet milieu [45]. Frigerio et al. have reported that beta cells secrete CXCL10 in response to inflammation [46]. The anti-inflammatory action of the GLP-1-cyclic AMP pathway through decrease of levels of STAT-1 was similar in human islets and MIN6 cells (Figs 3c, 7d). Although exendin-4 did have modest independent antiinflammatory action in selected experiments (Table 2, Figs 1a, 5b, 7a), addition of phosphodiesterase inhibitors augmented exendin- 4 action significantly. Beta cell-specific inhibition of phosphodiesterase could be a potential strategy to sustain the level of cyclic AMP generated by exendin-4. Tissue-specific expression of 11 families of phosphodiesterase isozymes has been reported [47]. Pancreatic beta cells predominantly express phosphodiesterase 3 and phosphodiesterase 4 [48]. Therefore we used cilostamide and rolipram, inhibitors of phosphodiesterase 3 and 4 respectively, to sustain exendin-4-mediated cyclic AMP levels (Fig. 8). The anti-inflammatory action of pentoxifylline, a general phosphodiesterase inhibitor, has also been reported in type 1 diabetic patients [49] and in animal models of type 1 diabetes $[6,50]$. Theophylline, another phosphodiesterase inhibitor, decreases the incidence of diabetes in BioBreeding rats [7]. In the presence of phosphodiesterase inhibitors, exendin-4-mediated phosphorylation of CREB at serine 133, a regulatory step needed for CREB activation, was sustained over time (Fig. 8). Previously, we have reported that CREB is needed for the anti-apoptotic effects of exendin-4 [19]. Thus the present study suggests that a combination of exendin- 4 and phosphodiesterase 3 and 4 inhibitors could decrease islet inflammation in addition to improving beta cell mass in patients with diabetes.

Acknowledgements This work was carried out with the use of resources and facilities at Denver VA Medical Center. We thank Islet Cell Resource Center-ABCC system and Islet Cell Resource Centers for providing human islets. This work was supported by a grant from American Diabetes Association (1-06-JF-40, to S. Pugazhenthi). We thank M. von Herrath (La Jolla Institute for Allergy and Immunology, San Diego, CA, USA) and R. Mahalingam (University of Colorado Denver, Aurora, CO, USA) for their critical reading of the manuscript.

Duality of interest The authors declare that there is no duality of interest associated with this manuscript.

\section{References}

1. Drucker DJ (2006) The biology of incretin hormones. Cell Metab 3:153-165

2. Aronoff DM, Canetti C, Serezani CH, Luo M, Peters-Golden M (2005) Cutting edge: macrophage inhibition by cyclic AMP (cAMP): differential roles of protein kinase $\mathrm{A}$ and exchange protein directly activated by cAMP-1. J Immunol 174:595-599

3. Sengupta TK, Schmitt EM, Ivashkiv LB (1996) Inhibition of cytokines and JAK-STAT activation by distinct signaling pathways. Proc Natl Acad Sci U S A 93:9499-9504

4. Sands WA, Palmer TM (2005) Inhibition of pro-inflammatory cytokine receptor signalling by cAMP in vascular endothelial cells. Biochem Soc Trans 33:1126-1128

5. Kawada N, Uoya M, Seki S, Kuroki T, Kobayashi K (1997) Regulation by cAMP of STAT1 activation in hepatic stellate cells. Biochem Biophys Res Commun 233:464-469

6. Liang L, Beshay E, Prud'homme GJ (1998) The phosphodiesterase inhibitors pentoxifylline and rolipram prevent diabetes in NOD mice. Diabetes 47:570-575

7. Rabinovitch A, Sumoski WL (1990) Theophylline protects against diabetes in $\mathrm{BB}$ rats and potentiates cyclosporine protection. Diabetologia 33:506-508 
8. Baggiolini M (2001) Chemokines in pathology and medicine. J Intern Med 250:91-104

9. Luster AD, Ravetch JV (1987) Biochemical characterization of a gamma interferon-inducible cytokine (IP-10). J Exp Med 166:1084-1097

10. Luster AD (1998) Chemokines-chemotactic cytokines that mediate inflammation. N Engl J Med 338:436-445

11. Neville LF, Mathiak G, Bagasra O (1997) The immunobiology of interferon-gamma inducible protein $10 \mathrm{kD}$ (IP-10): a novel, pleiotropic member of the $\mathrm{C}-\mathrm{X}-\mathrm{C}$ chemokine superfamily. Cytokine Growth Factor Rev 8:207-219

12. Christen U, von Herrath MG (2004) IP-10 and type 1 diabetes: a question of time and location. Autoimmunity 37:273-282

13. Cardozo AK, Proost P, Gysemans C, Chen MC, Mathieu C, Eizirik DL (2003) IL-1beta and IFN-gamma induce the expression of diverse chemokines and IL-15 in human and rat pancreatic islet cells, and in islets from pre-diabetic NOD mice. Diabetologia 46:255-266

14. Morimoto J, Yoneyama H, Shimada A et al (2004) CXC chemokine ligand 10 neutralization suppresses the occurrence of diabetes in nonobese diabetic mice through enhanced beta cell proliferation without affecting insulitis. J Immunol 173:7017-7024

15. Nicoletti F, Conget I, Di Mauro M et al (2002) Serum concentrations of the interferon-gamma-inducible chemokine IP10/CXCL10 are augmented in both newly diagnosed type I diabetes mellitus patients and subjects at risk of developing the disease. Diabetologia 45:1107-1110

16. Schulthess FT, Paroni F, Sauter NS et al (2009) CXCL10 impairs beta cell function and viability in diabetes through TLR4 signaling. Cell Metab 9:125-139

17. Roep BO, Kleijwegt FS, van Halteren AG et al (2009) Islet inflammation and CXCL10 in recent-onset type 1 diabetes. Clin Exp Immunol 159:338-343

18. Sarkar SA, Kutlu B, Velmurugan K et al (2009) Cytokinemediated induction of anti-apoptotic genes that are linked to nuclear factor kappa-B (NF-kappaB) signalling in human islets and in a mouse beta cell line. Diabetologia 52:1092-1101

19. Sarkar SA, Gunter J, Bouchard R et al (2007) Dominant negative mutant forms of the cAMP response element binding protein induce apoptosis and decrease the anti-apoptotic action of growth factors in human islets. Diabetologia 50:1649-1659

20. Miyazaki J, Araki K, Yamato E et al (1990) Establishment of a pancreatic beta cell line that retains glucose-inducible insulin secretion: special reference to expression of glucose transporter isoforms. Endocrinology 127:126-132

21. Schweppe RE, Klopper JP, Korch C et al (2008) Deoxyribonucleic acid profiling analysis of 40 human thyroid cancer cell lines reveals cross-contamination resulting in cell line redundancy and misidentification. J Clin Endocrinol Metab 93:4331-4341

22. Majumder S, Zhou LZ, Chaturvedi P, Babcock G, Aras S, Ransohoff RM (1998) p48/STAT-1alpha-containing complexes play a predominant role in induction of IFN-gamma-inducible protein, $10 \mathrm{kDa}$ (IP-10) by IFN-gamma alone or in synergy with TNF-alpha. J Immunol 161:4736-4744

23. Abdi R, Means TK, Luster AD (2003) Chemokines in islet allograft rejection. Diabetes Metab Res Rev 19:186-190

24. Eizirik DL, Colli ML, Ortis F (2009) The role of inflammation in insulitis and beta-cell loss in type 1 diabetes. Nat Rev Endocrinol 5:219-226

25. Yeruva S, Ramadori G, Raddatz D (2008) NF-kappaB-dependent synergistic regulation of CXCL10 gene expression by IL-1beta and IFN-gamma in human intestinal epithelial cell lines. Int $\mathrm{J}$ Colorectal Dis 23:305-317

26. Campbell RK, Miller S (2009) New therapeutic horizons: mapping the future of glycemic control with incretin-based therapy. Diabetes Educ 35:731-734
27. Iwai T, Ito S, Tanimitsu K, Udagawa S, Oka J (2006) Glucagonlike peptide-1 inhibits LPS-induced IL-1beta production in cultured rat astrocytes. Neurosci Res 55:352-360

28. Kim S, Moon M, Park S (2009) Exendin-4 protects dopaminergic neurons by inhibition of microglial activation and matrix metalloproteinase- 3 expression in an animal model of Parkinson's disease. J Endocrinol 202:431-439

29. Hadjiyanni I, Baggio LL, Poussier P, Drucker DJ (2008) Exendin4 modulates diabetes onset in nonobese diabetic mice. Endocrinology 149:1338-1349

30. Zhang J, Tokui Y, Yamagata K et al (2007) Continuous stimulation of human glucagon-like peptide-1 (7-36) amide in a mouse model (NOD) delays onset of autoimmune type 1 diabetes. Diabetologia 50:1900-1909

31. Yang Z, Chen M, Carter JD et al (2006) Combined treatment with lisofylline and exendin- 4 reverses autoimmune diabetes. Biochem Biophys Res Commun 344:1017-1022

32. Ogawa N, List JF, Habener JF, Maki T (2004) Cure of overt diabetes in NOD mice by transient treatment with anti-lymphocyte serum and exendin-4. Diabetes 53:1700-1705

33. Sherry NA, Chen W, Kushner JA et al (2007) Exendin-4 improves reversal of diabetes in NOD mice treated with anti-CD3 monoclonal antibody by enhancing recovery of beta-cells. Endocrinology 148:5136-5144

34. Kim SJ, Nian C, Doudet DJ, McIntosh CH (2009) Dipeptidyl peptidase IV inhibition with MK0431 improves islet graft survival in diabetic NOD mice partially via $\mathrm{T}$ cell modulation. Diabetes 58:641-651

35. Couto FM, Minn AH, Pise-Masison CA et al (2007) Exenatide blocks JAK1-STAT1 in pancreatic beta cells. Metabolism 56:915918

36. Christen U, McGavern DB, Luster AD, von Herrath $M G$, Oldstone MB (2003) Among CXCR3 chemokines, IFN-gammainducible protein of $10 \mathrm{kDa}$ (CXC chemokine ligand (CXCL) 10) but not monokine induced by IFN-gamma (CXCL9) imprints a pattern for the subsequent development of autoimmune disease. J Immunol 171:6838-6845

37. Berg AK, Korsgren O, Frisk G (2006) Induction of the chemokine interferon-gamma-inducible protein-10 in human pancreatic islets during enterovirus infection. Diabetologia 49:2697-2703

38. Tanaka S, Nishida Y, Aida K et al (2009) Enterovirus infection, CXC chemokine ligand 10 (CXCL10), and CXCR3 circuit: a mechanism of accelerated beta-cell failure in fulminant type 1 diabetes. Diabetes 58:2285-2291

39. Jun HS, Yoon JW (2001) The role of viruses in type I diabetes: two distinct cellular and molecular pathogenic mechanisms of virus-induced diabetes in animals. Diabetologia 44:271-285

40. Roivainen M, Rasilainen S, Ylipaasto P et al (2000) Mechanisms of coxsackievirus-induced damage to human pancreatic beta-cells. $\mathrm{J}$ Clin Endocrinol Metab 85:432-440

41. Liu D, Cardozo AK, Darville MI, Eizirik DL (2002) Doublestranded RNA cooperates with interferon-gamma and IL-1 beta to induce both chemokine expression and nuclear factor-kappa Bdependent apoptosis in pancreatic beta-cells: potential mechanisms for viral-induced insulitis and beta-cell death in type 1 diabetes mellitus. Endocrinology 143:1225-1234

42. Donath MY, Storling J, Maedler K, Mandrup-Poulsen T (2003) Inflammatory mediators and islet beta-cell failure: a link between type 1 and type 2 diabetes. J Mol Med 81:455-470

43. Donath MY, Schumann DM, Faulenbach M, Ellingsgaard H, Perren A, Ehses JA (2008) Islet inflammation in type 2 diabetes: from metabolic stress to therapy. Diabetes Care 31(Suppl 2): S161-S164

44. Ehses JA, Perren A, Eppler E et al (2007) Increased number of islet-associated macrophages in type 2 diabetes. Diabetes $56: 2356-2370$ 
45. von Herrath M, Holz A (1997) Pathological changes in the islet milieu precede infiltration of islets and destruction of beta-cells by autoreactive lymphocytes in a transgenic model of virus-induced IDDM. J Autoimmun 10:231-238

46. Frigerio S, Junt T, Lu B et al (2002) Beta cells are responsible for CXCR3-mediated T cell infiltration in insulitis. Nat Med 8:1414-1420

47. Omori K, Kotera J (2007) Overview of PDEs and their regulation. Circ Res 100:309-327

48. Parker JC, VanVolkenburg MA, Ketchum RJ, Brayman KL, Andrews KM (1995) Cyclic AMP phosphodiesterases of human and rat islets of Langerhans: contributions of types III and IV to the modulation of insulin secretion. Biochem Biophys Res Commun 217:916-923

49. MacDonald MJ, Shahidi NT, Allen DB, Lustig RH, Mitchell TL, Cornwell ST (1994) Pentoxifylline in the treatment of children with new-onset type I diabetes mellitus. JAMA 271:27-28

50. Stosic-Grujicic S, Maksimovic D, Badovinac V et al (2001) Antidiabetogenic effect of pentoxifylline is associated with systemic and target tissue modulation of cytokines and nitric oxide production. J Autoimmun 16:47-58 